\title{
THE MOSS FLORA OF KOSTIN AND BALKHACH MOUNTAINS (SREDINNYJ KAMCHATSKY RANGE, RUSSIAN FAR EAST)
}

\author{
БРИОФЛОРА ГОР КОСТИНА И БАЛХАЧ \\ (СРЕДИННЫЙ КАМЧАТСКИЙ ХРЕБЕТ, РОССИЙСКИЙ ДАЛЬНИЙ ВОСТОК)
}

\author{
V.E. FEDOSOV ${ }^{1}$ \\ В.Э. ФЕДОСОВ ${ }^{1}$
}

\begin{abstract}
The moss flora was explored above timber line in Kostin \& Balkhach Mts. in the elfin wood formed by Pinus pumila and Duschekia fruticosa and in alpine belts. Annotated list of 179 species is provided. Five species are new to Kamchatka (Encalypta procera, Pseudohygrohypnum subeugyrium, Schistidium obscurum, Stereodon fauriei, Tayloria froelichiana) and many rare species are also found in this area, including Blindia acuta, Cnestrum schistii, Ditrichum heteromallum, D. pallidum, Encalypta affinis, E. alpina, E. brevicolla, Mielichhoferia mielichhoferiana, Orthothecium strictum, Tortella alpicola, etc.
\end{abstract}

Резюме

Исследована бриофлора гор Костина и Балхач выше верхней границы леса. В стланиковом и гольцовом поясах выявлено 179 видов мхов. Приводится их краткий аннотированный список. Пять видов (Encalypta procera, Pseudohygrohypnum subeugyrium, Schistidium obscurum, Stereodon fauriei, Tayloria froelichiana) выявлены на Камчатке впервые; ряд видов (Blindia acuta, Cnestrum schistii, Ditrichum heteromallum, D. pallidum, Encalypta affinis, E. alpina, E. brevicolla, Mielichhoferia mielichhoferiana, Orthothecium strictum, Tortella alpicola и др.) редок на её территории.

KEYWORDS: diorite, floristics, Kamchatka, mosses, Sredinnyj Kamchatsky Range

Kostin and Balkhach Mountains $\left(55^{\circ} 10^{\prime} \mathrm{N}\right.$, $158^{\circ} 07^{\prime}$ E) are situated in the central part of Kamchatka Peninsula, ca. $70 \mathrm{~km}$ W from Milkovo, representing an eastern spur of Sredinnyj Kamchatsky Range (Fig. 1). Climate and vegetation of this territory are similar to those of Bystrinsky Nature Park described by Czernyadjeva \& Ignatova (2008); however coniferous forests are absent in studied area. At the same time, it contrasts to Bystrinsky Nature Park in bedrock composition. The intrusive diorites, quartz diorites, diorite-porphyry, and andesite-basaltic effusives are the most widespread in Kostin Mt. (1752 m), Balkhach Mt. (1702.3 m), and adjacent local ridges. In addition, the rocks of hydrothermic origin, rich in iron occur in a cirque of Balkhach Mt. The slopes are strongly dissected, having numerous cliffs and cirques. Average altitudes of ridges are commonly 1200-1400 $\mathrm{m}$, being 700-800 $\mathrm{m}$ above valley bottoms. The main watershed slopes are very steep, usually ca. $40^{\circ}$, covered by lumpy colluvium and having numerous cliffs. More gentle slopes have developed vegetation, represented by various mountain tundras, alternating with communities of Pinus pumila and Duschekia fruticosa thickets which are substituting by birch forests below $900 \mathrm{~m}$.

The moss flora of Mt. Kostin vicinity was explored in September 2010, focusing on the altitudinal range ca. $900-1500 \mathrm{~m}$. As much as 179 species were identified from ca. 400 specimens collected here.

1 - Moscow State University, Biological Faculty, Vorob’ovy gory, Moscow 119991 Russia - Россия 119991

Москва, Воробьевы горы, Московский гос. университет, Биологический факультет; fedosov_v@mail.ru 


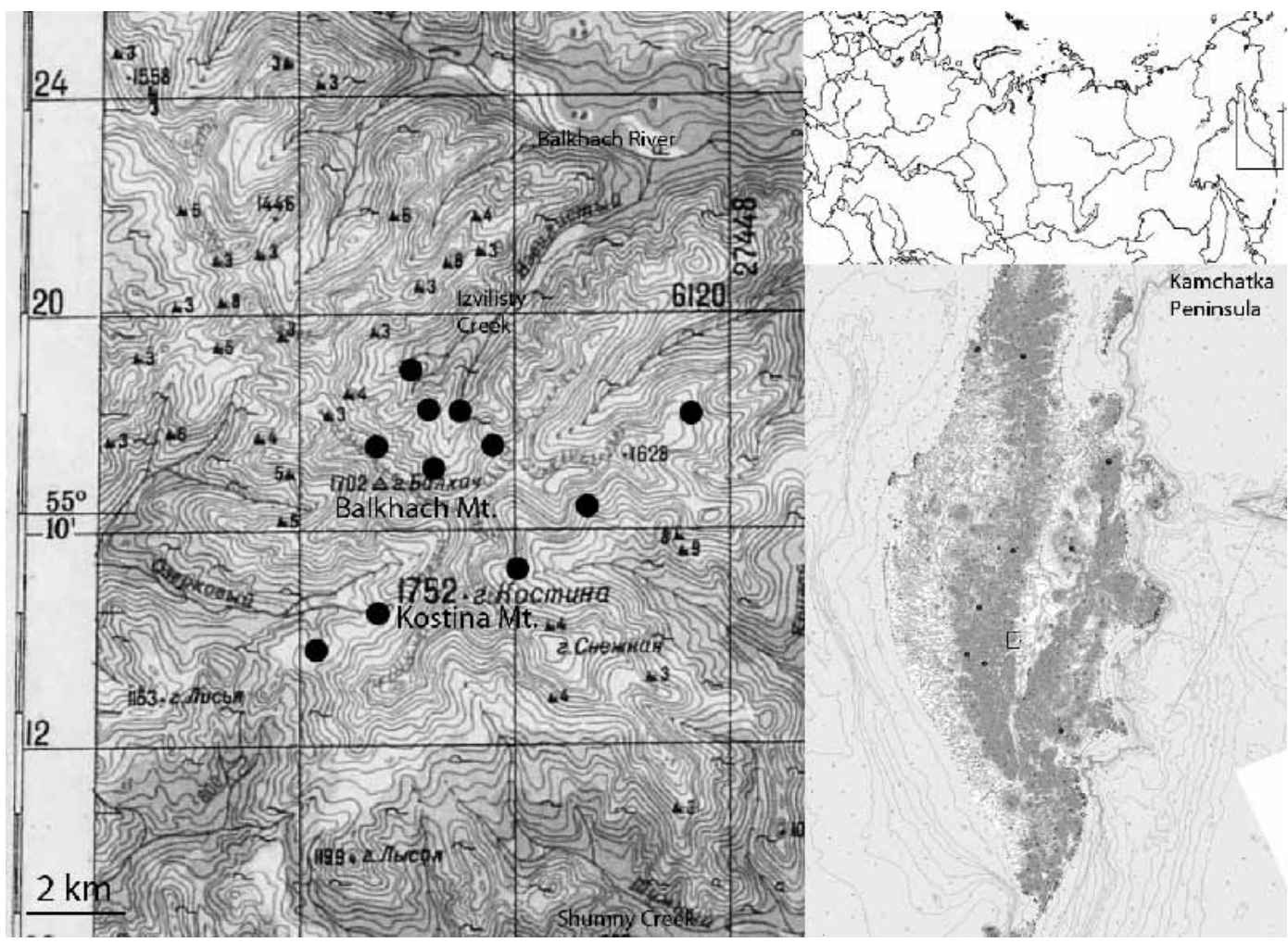

Fig. 1. Main collecting localities.

Species of following list are annotated with the frequency (Un - unique; Rar - rare; Sp - sparse; Fr - frequent) based on herbarium specimens supplemented by field observations, altitudinal range in meter [in square brackets], habitats, substrate, associated species and sporophyte presence $(\mathrm{S}+$ ). Species names are according to Ignatov, Afonina, Ignatova et al. (2006) and Ignatova et al. (2010).

Abietinella abietina - Un [1100] on flat turf covering diorite rock, with Encalypta rhaptocarpa, Rhytidium rugosum, Tortula mucronifolia.

Amphidium lapponicum - Sp [1300-1500] on basaltic rocks. S+.

Andreaea nivalis - Rar [950] locally abundant on moist surface of diorite cliff, with A. rupestris, Arctoa fulvella, Ochyraea duriuscula. S+.

A. rupestris - Fr [900-1500] on basaltic and diorite cliffs and boulders. S+.

Anomobryum julaceum - Un [1240] in shaded niche at basaltic cliff base, on fine soil sediments.

Arctoa fulvella - Sp [950-1300] on fine soil sediments on steep rocky slopes, cliff niches and snow beds. S+. Aulacomnium palustre - Rar [900-1100] in moss communities at wet creek banks.
A. turgidum - Sp [1000-1300] in rocky tundra and moss communities at creek banks.

Bartramia ithyphylla - Sp [1000-1500] in dwarf-shrub tundra and in niches of basaltic rocks. S+.

Blindia acuta - Un [1300] on moist base of diorite rock, with Schistidium papillosum.

Brachytheciastrum velutinum - Un [1250] on ledge of basaltic cliff covered with fine soil, as admixture in Pseudoleskeella rupestris mat.

Brachythecium cirrosum - Sp [1300-1500] on ledges and flat surfaces of basaltic cliffs and boulders.

B. mildeanum - Un [950] in wet depression near creek bed.

B. salebrosum - Un [970] tundra moss community, on moist humus soil.

Bryoerythrophyllum recurvirostrum - Sp [900-1500] on fine soil sediments at creek banks, roadsides, cliff niches and bases. $\mathrm{S}+$.

Bryoxiphium norvegicum - Rar [1300] on steep walls of diorite boulder and cliff niches.

Bryum argenteum - Rar [950] On basaltic cliff ledge covered with fine soil, locally abundant.

B. creberrimum - Un [900] On fine soil sediments at roadside, with Ditrichum cylindricum and Oligotrichum aligerum. $\mathrm{S}+$.

B. pseudotriquetrum - Sp [900-1400] in moss com- 
munities at wet creek banks and snow beds.

B. schleicheri-Un [900] in wet depression near creek bank.

Bucklandiella microcarpa - Fr [900-1300] on diorite rocks and boulders and in rocky tundra. S+.

B. sudetica - Sp [900-1100] on diorite boulders.

Calliergon cordifolium - Sp [900-1000] at wet creek banks and in wet depressions among moraine hillocks on the bottom of Balkhach Mt. cirque.

Campylidium sommerfeltii - Un [930] in Duschekia fruticosa community on steep slope of creek hollow, on fallen wood.

Campylium stellatum - Rar [1000; 1400] at wet creek bank, at most base of basaltic rock on fine soil.

Ceratodon purpureus - Sp [900-1400] on fine soil sediments at creek banks, roadsides, cliff niches and bases. S+.

Cinclidium stygium - Un [1000] in wet depression at confluence of two creeks with Scorpidium revolvens, Calliergon cordifolium.

Climacium dendroides - Rar [950; 1100] on wet bank and turf-covered cliff base near creeks.

Cnestrum schistii - Sp [1000-1200] on bare soil at eroded slopes and niches in tundra mostly with $\mathrm{He}-$ paticae. S+.

Codriophorus brevisetus - Un [1000] on moist diorite boulder, covered with sandy alluvium at creek bank.

C. corrugatus - Rar [900-1200] on moist diorite boulders in creeks and alluvium at creek banks. S+.

Conostomum tetragonum - Rar [1200-1400] on rocky snow beds on soil. $\mathrm{S}+$.

Cratoneuron filicinum - Un [900] on wet creek bank near water.

Cynodontium strumiferum - Un [1100] on decayed base of Pinus pumila schrub, with Plagiothecium laetum and Dicranum fragilifolium.

C. tenellum - Rar $[950 ; 1000]$ on moist diorite cliffs. S+.

Dichodontium palustre - Rar [900-1100] on wet creek banks near water.

D. pellucidum - Rar [950; 980] on fine soil at eroded slopes to creek hollow; on wet diorite rock.

Dicranella cerviculata - Un [950] on loamy soil on eroded roadside with Pohlia proligera. S+.

D. crispa - Rar [900-1000] on loamy and fine soil at the bottom of cirques near roads and creeks. S+.

D. grevilleana - Un [1400] on fine soil on rocky snow bed with Pohlia drummondii.

D. subulata - Sp [900-1100] on loamy and fine soil barings near roads, on steep slopes, in tundra. $\mathrm{S}+$.

D. varia - Un [980] on moist fine soil sediments near creek water.

Dicranum acutifolium - Un [1100] in dry dwarf-schrub moss tundra at the top of moraine rib.

D. angustum - Sp [950-1100] on wet hummocky tundra at the base of slope with Sphagnum spp., Aula- comnium palustre and Oncophorus wahlenbergii.

D. elongatum - Sp [900-1200] in wet moss tundra in flat creek hollows and at slope bases. S+.

D. flexicaule - Sp [900-1100] on soil in Pinus pumila and Duscheckia fruticosa communities.

D. fragilifolium - Un [1100] on decayed base of Pinus pumila schrub, with Plagiothecium laetum and $C y$ nodontium strumiferum.

D. fuscescens - Un [950] on decayed base of Duscheckia fruticosa schrub.

D. majus - Fr [900-1300] on soil in different tundra communities, at edges of slopes and turf-covered rocks. S+.

D. scoparium - Un [930] on soil in Duscheckia fruticosa community with Sanionia uncinata and Sciuro-hypnum reflexum.

D. spadiceum - Un [1200] on dry rocky tundra at the top of moraine ridge with Rhytidium rugosum.

Didymodon icmadophilus - Un [1400] on basaltic rock ledge, covered with fine soil sediments.

Distichium capillaceum - Fr [900-1500] on bare soil near roads, on steep slopes, in tundra, in cliff niches. $\mathrm{S}+$.

D. inclinatum - Rar [1400] on moist ledges and crevices of basaltic rocks. $\mathrm{S}+$.

Ditrichum cylindricum - Un [900] on fine soil at roadside with Bryum creberrimum and Oligotrichum aligerum. $\mathrm{S}+$.

D. flexicaule - Sp [1400] on ledges and at bases of basaltic rocks, in tundra.

D. heteromallum - Rar $[1000 ; 1200]$ on flat turf-covered surface and at base of diorite rock outcrops.

D. lineare - Rar [1200-1300] on ledges of diorite rocks.

D. pallidum - Un [1200] on soil at diorite cliff base with Tortula hoppeana. S+.

Drepanocladus aduncus - Un [1000] at wet creek bank near water.

Encalypta affinis - Rar [1050] at the edge of steep eroded slope with Cnestrum schistii, Pohlia cruda and Saelania glaucescens. S+.

E. alpina - Rar [1300-1500] on ledges and flat surfaces of basaltic cliffs and boulders. $\mathrm{S}+$.

E. brevicolla - Un [1100] on flat turf covered diorite rock with E. rhaptocarpa, Rhytidium rugosum, Tortula mucronifolia. S+.

E. procera - Rar [1300-1500] on ledges and in niches of basaltic rocks. $\mathrm{S}+$.

E. rhaptocarpa - Sp [1000-1500] on ledges and at bases of basaltic and diorite rocks. S+.

Eurhynchiastrum pulchellum - Rar [1300-1500] on turf-covered ledges of basaltic rocks.

Fissidens bryoides - Un [1100] in soil niche in dwarfschrub moss tundra with Hepaticae.

Grimmia donniana - Sp [950-1300] on moist diorite boulders near creeks and in snow beds. $\mathrm{S}+$. 
G. longirostris - Rar [1050] on lumpy colluvium in snow bed at base of rocky slope, with Racomitrium lanuginosum, Grimmia donniana. S+.

G. reflexidens - Un [1050] on lumpy colluvium in snow bed at base of rocky slope, with Racomitrium lanuginosum, Grimmia donniana, G. longirostris. S+.

Helodium blandowii - Rar [950; 1000] in wet tundra in creek hollows at slope bases.

Hygrohypnella ochracea - Rar [900; 950] on wet diorite cliff and on boulder near creek water. S+.

Hygrohypnum luridum - Un [900] on wet boulder near creek.

Hylocomiastrum pyrenaicum - Sp [1000-1300] in rocky tundra and turf covered diorite outcrops.

Hylocomium splendens - Fr [900-1200] on soil in moderately damped dwarf-schrub moss tundra, $P i$ nus pumila communities, turf covered rocks etc.

Hymenoloma crispulum - Fr [900-1200] on basaltic and diorite rocks and on fine soil in snow beds. $\mathrm{S}+$.

Hypnum cupressiforme - Un [1300] on moist turf-covered basaltic rock with Distichium inclinatum, Brachythecium cirrosum and Mnium lycopodioides.

Isopterygiopsis alpicola - Un [1420] on thin fine soil layer in moist niche of basaltic cliff.

I. pulchella - Sp [1000-1500] in cliff and soil niches on fine soil and humus. S+.

Kiaeria glacialis - Rar [1050-1300] in rocky moss tundra near snow beds.

K. starkei - Sp [950-1350] in moist moss communities near creeks, in snow beds, at the bases of steep slopes, mostly on fine soil. S+.

Leptobryum pyriforme - Rar [900-950] on fine soil at eroded roadside with Oligotrichum aligerum and Pogonatum urnigerum $\mathrm{S}+$.

Lescuraea incurvata - Rar [1000] on moist diorite cliff base, covered with fine soil alluvium.

L. radicosa - Un [930] in Duscheckia fruticosa community on bottom of creek hollow, on sandy alluvium.

L. saxicola - Sp [1000-1500] on turf-covered ledges of diorite and basaltic rocks.

Loeskypnum badium - Un [1020] in wet moss community at the bottom of creek hollow near slope base.

Mielichhoferia mielichhoferiana - Rar [950] on ledges of rock with high Fe content on the bottom of Balkhach Mt. cirque.

Mnium lycopodioides - Sp [1100-1400] in niches of diorite and basaltic cliffs, in Duscheckia fruticosa community.

M. spinosum - Un [1050] on turf-covered surface of diorote boulder.

M. thomsonii - Un [1000] on moist diorite cliff base, covered with fine soil alluvium.

Myurella julacea - Rar [1370; 1420] on fine soil covered ledges of basaltic rocks.
M. tenerrima - Un [1420] on ledge of basaltic cliff, intermixed with Encalypta procera.

Niphotrichum canescens - Fr [900-1300] on sandy and fine soil sediments at creek banks, in snow beds.

N. muticum - Un [1070] on sandy alluvium at creek bank. S+.

$N$. panschii - Rar $[1000 ; 1050]$ on alluvium at creek banks.

Ochyraea duriuscula - Sp [900-1050] on moist diorite boulders and rocks near creeks. $\mathrm{S}+$.

Oligotrichum aligerum - Fr [900-1250] on fine soil sediments at roadsides, creek banks and other disturbed places. S+.

O. falcatum - Rar [1050] on diorite boulder near snow bed with Grimmia spp. and Racomitrium lanuginosum, locally abundant.

O. hercynicum - Rar [1300] on fine soil in snow beds.

O. parallelum - Fr [900-1000] on bare fine soil at roadsides, creek banks and other disturbed places. S+.

Oncophorus virens - Un [980] in wet hummocky tundra with Sphagnum compactum.

O. wahlenbergii - Sp [950-1100] in wet tundra communities near bases of slopes and creek banks. S+.

Orthothecium chryseon - Rar [1420] on moist base of basaltic cliff, covered by fine soil with Brachythecium cirrosum.

O. strictum - Rar $[1300 ; 1420]$ in cracks of basaltic cliffs with Brachythecium cirrosum, Mnium lycopodioides, Distichium inclinatum.

Oxystegus tenuirostris - Un [1050] on humus soil in sparse tundra community near diorite rock.

Paludella squarrosa - Rar [900] in wet depressions among moraine hillocks on the bottom of Balkhach Mt. cirque near upper limit of forest belt.

Philonotis fontana - Sp [900-1100] in moss communities near creeks; in wet turf-covered placer near base of rock.

P. tomentella - Un [1000] in wet depression at confluence of two creeks with on hummock with Aulacomnium palustre.

Plagiobryum demissum - Un [1050] in dry rocky moss tundra, covering placer. $\mathrm{S}+$.

Plagiomnium ellipticum - Rar [1020; 1100] in moss communities on the bottom of creek hollows.

P. medium - Un [1000] in community of Duscheckia fruticosa on steep slope of cirque, on litter with Sciuro-hypnum reflexum.

P. rostratum - Un [900] in Duscheckia fruticosa community in creek hollow, on wet litter.

Plagiopus oederianus - Un [1420] on moist base of basaltic rock.

Plagiothecium cavifolium - Un [1000] in shaded niche between diorite boulders, on fine soil.

P. laetum - Rar $[950 ; 1020]$ on decayed bases of Pinus pumila tickets. S+. 
Platydyctia jungermannioides - Un [1300] in crack of basaltic rock on fine soil.

Pleurozium schreberi - Fr [900-1200] on soil in dwarfshrub moss tundra, Pinus pumila and Duscheckia fruticosa communities.

Pogonatum urnigerum - Sp [900-1350] on bare fine soil sediments at roadsides, near creeks, at rock bases and in snow beds.

Pohlia andrewsii - Un [1000] on fine soil near road with P. proligera and Pogonatum urnigerum.

P. cruda - Fr [900-1500] on humus and fine soil on cliff ledges, in niches, different tundra and elfin wood formations. $\mathrm{S}+$.

P. crudoides - Sp [950-1300] on diorite rocks and on sandy alluvium at creek banks. S+.

P. drummondii- $\operatorname{Rar}[1000 ; 1200]$ on fine soil on creek bank and in snow bed.

P. elongata - Un [1050] on turf-covered surface of diorite boulder. $\mathrm{S}+$.

P. filum - Un [950] on moist fine soil at creek bank.

P. nutans - Fr [900-1320] on turf-covered rocks and bare soil in tundra and elfin wood formations. S+.

P. proligera - $\operatorname{Fr}$ [900-1100] on fine soil, sandy and loamy alluvium and bare patches.

P. wahlendbergii - Rar $[950 ; 1000]$ on wet alluvium near water at creek bank and near the pool at the cliff base.

Polytrichastrum alpinum - Fr [900-1500] on soil in tundra, snow beds, turf-covered rocks, Pinus pumila communities. S+.

P. longisetum - Un [950] on soil in Duscheckia fruticosa community.

P. sexangulare - Un [1250] on fine soil in snow bed with Kiaeria starkey.

Polytrichum commune - Un [920] on moss community in moist depression between moraine mounds on the bottom of Balkhach Mt. cirque.

P. hyperboreum - Un [1300] in snow bed on fine soil with Pohlia sp and Sanionia uncinata.

P. juniperinum $-\operatorname{Fr}[900-1300]$ on dry \pm disturbed places in tundra and Pinus pumila communities. S+.

P. piliferum - Rar $[1000 ; 1240]$ on dry turf-covered rocks and fine soil deposits.

Pseudohygrohypnum subeugyrium - Un [1240] in moist shaded niche between basaltic boulders.

Pseudoleskeella papillosa - Un [1240] on fine soil deposits at base of basaltic cliff.

P. rupestris - Sp [1100-1400] on ledges and niches of basaltic, or, rarer, diorite rocks.

Racomitrium lanuginosum - Fr [1000-1500] in moist rocks and boulders near creeks and in snow beds, in rocky tundra etc. with preference to diorites.

Rhizomnium andrewsianum - Un [1050] in moist humus soil niche in tundra.

R. punctatum - Un [900] in open Duschekia fruticosa community in creek hollow, on wet litter.

Rhytidium rugosum - Sp [1000] in rocky tundra and turf-covered rock surfaces.

Saelania glaucesces - Rar $[1000 ; 1240]$ at the edge of steep eroded slope with on humus soil mainly under Cassiope \& Arctous canopy with Encalypta affinis and Cnestrum schistii, locally abundant; in niche of basaltic rock. $\mathrm{S}+$.

Sanionia uncinata - Fr [900-1500] on soil in tundra, snow beds, turf-covered rocks, Pinus pumila and Duschekia fruticosa communities. S+.

Schistidium cf. bakalinii-Un [950] on boulder of rock with high Fe content. S+.

S. obscurum - Un [950] on moist surface of diorite boulder near creek. S+.

S. papillosum - Sp [900-1300] on moist diorite and basaltic rocks. $\mathrm{S}+$.

S. cf. sibiricum - Un [950] on moist diorite boulder with Hymenoloma crispulum and Grimmia donniana. $\mathrm{S}+$.

S. sordidum - Fr [900-1100] on moist diorite cliffs and boulders near creeks. S+.

S. tenuinerve - Rar [1000; 1300] on diorite boulder, covered with alluvium near creek and on moist basaltic rock.

Sciuro-hypnum laetum - Rar [950; 1000] in moist moss tundra and in creek hollow on sandy alluvium.

S. plumosum - Rar $[950 ; 1000]$ in Pinus pumila community on steep slope of ridge and in creek hollow, in Duschekia fruticosa community.

S. reflexum - Sp [900-1000] in Pinus pumila and Duschekia fruticosa communities on litter, fallen wood and shrub bases.

Scorpidium revolvens - Un [1000] in wet depression at confluence of two creeks with Cinclidium stygium and Calliergon cordifolium.

Sphagnum capillifolium - Rar [1000] on steep slope, covered with open Pinus pumila community.

S. compactum - Rar [1000] in wet tundra in lower parts of steep slopes.

S. fuscum - Rar $[1000 ; 1200]$ in wet tundra in lower parts of steep slopes.

S. girgensohnii - Rar $[950 ; 1000]$ in wet tundra in creek hollows at slope bases.

S. squarrosum - Rar [900-1100] in wet depressions near creeks in tundra and Duschekia fruticosa community.

Stereodon bambergeri - Un [1240] at base of basaltic rock.

S. fauriei-Un [1050] in mesic rocky dwarf-shrub moss tundra. S+.

S. holmenii - Un [1000] in open Pinus pumila community on the top of ridge, on soil.

S. plicatulus - Un [900] in open community of Duschekia fruticosa in creek hollow on litter. 
S. revolutus - Un [1240] on turf covered surface of basaltic rock with Brachythecium cirrosum.

Syntrichia norvegica - Rar [1240; 1420] on ledges of basaltic rocks.

S. ruralis - Rar [900] on moraine fine soil sediments on the bottom of Mt. Balkhach cirque.

Tayloria froelichiana - Rar [1240-1300] on moist ledges of basaltic rocks. S+.

Tetraplodon angustatus - Un [1000] in disturbed tundra patch at the top of ridge. S+.

T. mnioides - Rar $[1000 ; 1200]$ in rocky moss tundra on the edges of ridge. $\mathrm{S}+$.

Timmia comata - Sp [1100-1300] in niches and turf-covered bases of rocks, mainly basaltic.

Tomentypnum nitens - Rar [950-1050] in wet tundra at slope bases and near creeks.

Tortella alpicola - Sp [1240-1500] in basaltic rock crevices.

T. fragilis - Un [1300] on turf-covered base of basaltic rock.

T. tortuosa - Rar $[1050 ; 1240]$ on soil in open rocky tundra and turf-covered surface of basaltic boulder.

Tortula hoppeana - Sp [1000-1200] on ledges, turf covered surfaces and disturbed places near bases of rocks. S+.

T. mucronifolia - Rar $[1050 ; 1300]$ on basaltic and diorite rocks. $\mathrm{S}+$.

T. systylia - Un [1050] on steep base of diorite rock, covered with fine soil sediments. S+.

Trachycystis flagellaris - Un [1000] in shaded niche at the base of diorite rock on humus.

Warnstorfia exannulata - Un [1000] in wet depression at confluence of two creeks with Calliergon cordifolium.

W. sarmentosa - Un [950-1070] in wet tundra at slope base with Sphagnum compactum and Oncophorus wahlenbergii.

Five species are found in Kamchatka for the first time: Encalypta procera (simultaneously revealed by Czernyadjeva, 2010), Pseudohygrohypnum subeugyrium, Schistidium obscurum, Stereodon fauriei, and Tayloria froelichiana. In addition, a number of rare species have been found: Blindia acuta, Brachytheciastrum velutinum, Cnestrum schistii, Ditrichum heteromallum, D. pallidum, Encalypta affinis, E. alpina, E. brevicolla, Mielichhoferia mielichhoferiana, Orthothecium strictum, Tortella alpicola, etc. The high level of novelties in the course of a rather shorttime study needs a certain comments. First, the Sredinnyj Kamchatsky Range remains one of least studied regions of Kamchatka Peninsula (see
Czernyadjeva, 2005). At the same time, the climate of the territory is unusual for Kamchatka in rather low precipitation. Second, the only studied part of Sredinnyj Kamchatsky Range (Bystrinsky Nature Park, Czernyadjeva \& Ignatova, 2008) differs from Kostin \& Balkhach Mts. in prevailing types of rocks. In Kostin \& Balkhach Mts., common rocks are diorites, which, being rich in silicium dioxide, are also relatively rich in $\mathrm{Ca}$, while especially rich in $\mathrm{Ca}$ are basalts. In contrast, pyroclastic rocks, widespread in Bystrinsky Park, are relatively poor in Ca (Sidorenko, 1964). As a result, about ca. $10 \%$ of species are different from those found in Bystrinsky Park, despite its close position $(70 \mathrm{~km}$ from the studied area), much bigger size and relatively well studied moss flora yielded 292 species (Czernyadjeva \& Ignatova, 2008).

\section{ACKNOWLEDGEMETS}

I am grateful to Evgenyj Esin for Field work arrangement, Elena Ignatova and Michael Ignatov for confirmation of specimen identification, and Irina Czernyadjeva for providing data on moss distribution on Kamchatka Peninsula. The work was partly supported by RFBR, 09-0400678, Biodiversity Program of RAS and by Federal program «Scientific and educational personalities of innovative Russia 2009-2013», contracts №№ 14.740.11.0165 \& 16.740.111.0177.

\section{LITERATURE CITED}

CZERNYADJEVA, I.V. 2005. A check-list of the mosses of Kamchatka Peninsula (Far East). - Arctoa 14: 13-34.

[CZERNYADJEVA, I.V.] ЧЕРНЯДЬЕВА И.В. 2010. Новые находки мхов в Камчатской области. 4. - [New moss records in Kamchatskaja Province. 4.] Arctoa 19: 279.

CZERNYADJEVA, I.V. \& E.A. IGNATOVA 2008. Mosses of the Bystrinsky Nature Park (Kamchatka Peninsula, Russian Far East). - Arctoa 17: 49-62.

[SIDORENKO, A.V. (ed.)] СИДОРЕНКО А.В. (ред.) 1964. Геология CCCP. Том 31. Камчатка, Командорские и Курильские о-ва. Часть 1. Геологическое описание. [Geology of the USSR, Vol. 31. Kamchatka Peninsula, Commander and Kuril Islands. Part 1. Geologycal description] M., Heдpa [M., Nedra]: 734 pp.

IGNATOV, M.S., O.M. AFONINA, E.A. IGNATOVA et. al. 2006. Check-list of mosses of East Europe and North Asia. Arctoa 15: 1-130.

IGNATOVA, E.A., H.H. BLOM, D.V. GORYUNOV \& I.A. MILYUTINA 2010. On the genus Schistidium (Grimmiaceae, Musci) in Russia. - Arctoa 19: 113-138. 